Z Badań nad Książką i Księgozbiorami Historycznymi 2019, t. 13

The Studies into the History of the Book and Book Collections 2019, vol. 13

ISSN 1897-0788, e-ISSN 2544-8730

www.bookhistory.uw.edu.pl

DOI: 10.33077/uw.25448730.zbkh.2019.156

Boguchwała Tuszyńska

Independent scholar, Poznań

gloria@amu.edu.pl

\title{
On preserved and lost Ancient Maya books
}

\begin{abstract}
One of the greatest achievements of the Ancient Maya was a logo-syllabic writing system. The Maya left many glyphic inscriptions carved, incised or painted on different media. Unfortunately, from that rich scribal tradition only four manuscripts, known as codices, survived. They are painted on bark paper and contain, above all, almanacs with auguries. However, by looking at reports prepared by chroniclers during Colonial times, and documents transcribed in Mayan languages using the Latin alphabet, one can see that a variety of subjects could have been raised in lost codices.
\end{abstract}

Key words: Maya civilization - Maya glyphic books - scribes.

„Z Badań nad Książką i Księgozbiorami Historycznymi” - Udział zagranicznych recenzentów w ocenie publikacji; Stworzenie anglojęzycznej wersji wydawniczej publikacji; Digitalizacja tomów archiwalnych rocznika w celu zapewnienia otwartego dostępu do nich przez Internet oraz wdrożenie i utrzymanie cyfrowej platformy redakcyjnej - zadanie finansowane w ramach umowy nr 653/P-DUN/2019 ze środków Ministra Nauki i Szkolnictwa Wyższego przeznaczonych na działalność upowszechniającą naukę. 


\section{Introduction}

One of the greatest achievements of the Maya civilization, which inhabited the area currently belonging to five states of Mexico (Tabasco, Chiapas, Campeche, Yucatan, Quintana Roo), Guatemala, Belize and the western parts of Honduras and El Salvador, was the glyphic logo-syllabic writing ${ }^{1}$. It is difficult to determine with certainty when the Maya started using their writing system, but the earliest known inscription comes from the $3^{\text {rd }}-2^{\text {nd }}$ century B.C. from the site of San Bartolo (Guatemala) ${ }^{2}$. The Maya left behind texts carved in stone and wood, modelled in stucco, engraved on objects of jade, obsidian, shells, pyrite and bones, and painted on ceramic vessels, the walls of buildings and caves, and on pages of books called codices. While in the Classic Period (250-900), the inscriptions of Maya rulers recorded their history mostly in stone and mainly listed their genealogies, accessions, rituals and wars, on the other hand, in the Post-Classic Period (900-1500) very few texts of this type were written. When Europeans arrived in the Maya area, the cities of the Classic Period had long been abandoned, and the inscriptions surviving there had to wait for their explorers until the $19^{\text {th }}$ century. To this day, only a few old manuscripts have survived from this rich legacy, although writing them must have been very common, as confirmed by numerous chroniclers from Colonial times.

\section{First references to glyphic books}

The earliest mention of Maya codices is by Pedro Mártir de Anglería, an Italian historian in the service of the Catholic Monarchs of Spain, who in his work De Orbe Novo Decades, written in 1493-1523, referred to manuscripts sent to Europe from Mexico in $1519^{3}$. Both Judge López Mendel, travelling in Yucatan in 1553, and Franciscan Antonio de Ciudad Real, who arrived in Mexico in 1573, mentioned having seen Maya glyphic books ${ }^{4}$. Bishop Diego de Landa also wrote about them in Relación de las cosas de Yucatán $n^{5}$, prepared around 1566, although, as Matthew Restall and John F. Chuchiak showed, the work known today under this title is only a copy of original texts and constitutes an anonymous summary, compiled in the $17^{\text {th }}-18^{\text {th }}$ centuries ${ }^{6}$.

\footnotetext{
1 More about the Maya writing, among others, in the article: B. Tuszyńska, Glify Majów jako najbardziej rozwinięty system pisma w Mezoameryce [Maya glyphs as the most developed writing system in Mesoamerica], "Scripta Neophilologica Posnaniensia" 2018, vol. 18, pp. 293-317.

2 W.A. Saturno, D. Stuart, B. Beltrán, Early Maya Writing at San Bartolo, Guatemala, "Science" 2006, no. 311, pp. 1281-1283.

3 J.E. Thompson, Un Comentario al Códice de Dresde, México 1988, p. 14.

4 Ibidem, pp. 21-23.

5 D. de Landa, Relación de las cosas de Yucatán, Merida 1986, p. 21.

6 M. Restall, J.F. Chuchiak, A Reevaluation on the Authencity of Fray Diego de Landa'a Rela-
} 
Similarly, José de Acosta, in his Historia natural y moral de las Indias, published in Seville in 1590, talked about the Maya writing and their manuscripts. Of particular interest may be the fact that he mentions that one of his Jesuit brothers gathered Maya elders, who after a long debate decided to show him libraries containing manuscripts ${ }^{7}$. It may, therefore, be assumed that the Maya had archives where they stored their codices, although probably only a select group of people had access to them. Further, Franciscan Diego López de Cogolludo, whose Historia de Yucatán, published for the first time in Madrid in 1688 and based on the records of other chroniclers, including Pedro Sánchez de Aguilar, mentions that there was an archive with manuscripts in the town of Tix Ualach Tun ${ }^{8}$.

Presumably, one of the codices was seen by the Franciscan Andrés Avendaño y Loyola, who in 1696 visited the Itza Maya on the island of Tayasal (Guatemala) ${ }^{9}$, the Maya group who was the last to accept Christianity and Spanish rule. Such a late date should not come as a surprise, as J.F. Chuchiak, who has been searching through various archives from Colonial times for years, showed that despite an existing threat from friars, in the $16^{\text {th }}-17^{\text {th }}$ centuries, not only were old glyphic manuscripts in use, but new ones 10 were still produced.

\section{On paper production and the work of scribes}

While all the chroniclers mentioned above reported that Maya glyphic books were written on tree bark paper, more information about the process of paper production was provided in the $16^{\text {th }}$ century by Francisco Hernández, the physician of Philip II, king of Spain. Although he described the production of paper in Central Mexico just after the Conquest, it probably looked very similar in the Maya culture. Michael Coe, Stephen Houston, Mary Miller and Karl Taube, relying on the reports by Hernández, say that branches of trees from the mulberry family (especially Ficus cotinifolia) were softened overnight in water, and the next day the inner layer of bark was torn off. After being cleaned, wet fibres were stretched, placed in grid-like layers and beaten with stone bark beaters (Photo 1). In the case of codices, the long strips of paper obtained this way were folded like a screenfold or accordion,

\footnotetext{
ción de las cosas de Yucatán, "Ethohistory" 2002, vol. 49, no. 3, pp. 651-669.

J. de Acosta, Historia natural y moral de las Indias, Madrid 1894, pp. 160-161.

D. López de Cogolludo, Historia de Yucatán, Barcelona 2008, p. 275.

J.E. Thompson, op. cit., p. 17.

10 J.F. Chuchiak, The Images Speak: The Survival and Production of Hieroglyphic Codices and Their Use in Post Conquest Maya Religion (1580-1720), "Acta Mesoamericana” 2004, vol. 14, pp. 165-183.
} 
both sides were covered with a thin layer of calcium carbonate or plaster and smoothed with stone tools ${ }^{11}$.

Although in academic literature, the paper is usually called amate from the Nahuatl word amatl, the Maya used the term hu'un, both for the paper and objects made out of it. This word could be written down in glyphs in various ways, since many Maya logograms and syllabograms had interchangeable allographs. The most commonly used glyph depicted a kind of tied up ribbon or the image of the god personifying paper, but one of them showed a closed codex with covers of jaguar pelt (Photo 2), which was mentioned by D. de Landa ${ }^{12}$.

When the paper for the codex was prepared, specialized scribes-painters called ajtz'ihb started their work. Glyphs and scenes depicted on pages of the manuscript were painted with brushes made of animal hair, and in the case of particularly fine lines, styli made of reeds or bird feathers were probably used, as suggested by M. Coe and Justin Kerr ${ }^{13}$. Containers for paint were usually made of shell halves (Photo 3) or conch-like ceramic vessels.

Scribes-painters occupied an important position in the Maya society and Spanish chroniclers clearly emphasize that the art of writing and reading glyphs was only known to priests and members of the highest elites. According to D. de Landa, it was the highly respected priests called $A h K^{\prime}$ in who had access to books, taught reading and writing, passed on the knowledge of the calendar and rituals, advised rulers and were directly involved in preparing the most important ceremonies ${ }^{14}$.

Artefacts found at some archaeological sites indicate that the buildings were once used by scribes both as homes and as workshops. In one of the houses belonging to scribes in the Maya city of Aguateca (Guatemala), archaeologists found small stone mortars for preparing pigments, a bark beater for paper production and shell halves ${ }^{15}$. In Copan (Honduras), Structure 9N-82 in the Las Sepulturas served as a scribal residence for about 300-400 years, starting in $5^{\text {th }}$ century ${ }^{16}$. The facade of the building is decorated with figures of scribes or their divine patrons, holding painting implements in their hands (Photo 4).

Another example is Structure 10K-2 in the group Los Sabios, at the site of Xultun (Guatemala), where artefacts necessary for the production of paper and codices have been preserved. According to Franco D. Rossi, William

11 M. Coe, S. Houston, M. Miller, K. Taube, The Fourth Maya Codex, [in:] Maya Archeology 3, ed. Ch. Golden, S. Houston and J. Skidmore, San Francisco 2015, pp. 121-123.

12 D. de Landa, op. cit., p. 21.

13 M. Coe, J. Kerr, The Art of the Maya Scribe, New York 1998, p. 149.

14 D. de Landa, op. cit., p. 21.

15 T. Inomata, The Power and Ideology of Artistic Creation: Elite Craft Specialists in Classic Maya Society, "Current Anthropology" 2001, vol. 42, no. 3, pp. 326-327.

16 W. Fash, Scribes, warriors and kings. The City of Copán and the Ancient Maya, London 2001, p. 120. 
A. Saturno and Heather Hurst, the individuals bearing the title Taaj, mentioned in inscriptions there, could not only be authors of manuscripts, but also responsible for transferring their specialized knowledge ${ }^{17}$. This kind of scribal workshops were probably found in each of the major Maya cities. It is worth noting here that, for example, the town of Ek' Balam in Yucatan is well-known for its beautiful calligraphic texts, which, according to Alfonso Lacadena, may point to the existence of a school of specialized scribes ${ }^{18}$. Although no manuscript was found there, many inscriptions painted on the internal walls of the building and on the capstones have survived, and the glyphs written there resemble the preserved Maya codices in their style and manner of production.

\section{Extant Maya glyphic books}

The Maya must have produced and accumulated numerous manuscripts and presumably their production started as early as the beginning of the Classic Period (250-600). It is known that in the aftermath of the Conquest many codices were burned by Spanish church authorities, because they were considered the source of paganism of the local population. Some of the books could have been destroyed by the Maya themselves for fear of possible consequences from missionaries. Out of the significant number of codices mentioned by colonial chroniclers, only fragments of four have survived until today in relatively good condition; they bear names of the cities where they are currently housed. These are the: Dresden Codex, Madrid Codex, Maya Codex of Mexico ${ }^{19}$ and Paris Codex ${ }^{20}$.

The Dresden Codex, kept at the Saxon State Library (Sächsische Landesbibliothek) in Dresden, has the dimensions of $20.5 \times 9 \mathrm{~cm}, 3.56 \mathrm{~m}$ in length and includes 39 double-sided pages. It was purchased in Vienna in 1739 by Johann Christin Götze, the then director of the library ${ }^{21}$.

The Madrid Codex (Photo 5), kept at the Museum of America (Museo de América) in Madrid, measures 22.6 x $12.2 \mathrm{~cm}, 6.82 \mathrm{~m}$ in length and includes

17 F.D. Rossi, W.A. Saturno, H. Hurst, Maya Codex Book Production and the Politics of Expertise: Archaelogy of a Classsic Period Household at Xultun, Guatemala, "American Anthropologist" 2015, vol. 117, pp. 116-132. pp. 64-69.

1 A. Lacadena, Los jeroglificos de Ek ,Balam, “Arqueología Mexicana” 2005, vol. 13, no. 76,

19 The Maya Codex of Mexico was formerly known as the Grolier Codex from the name of the club in New York where it was first presented. The new name was officially announced during the symposium organized at the National Museum of Anthropology in Mexico City on August 30-31, 2018.

20 Detailed information on all four surviving codices and illustrations may be found on the Foundation for the Advancement of Mesoamerican Studies website: http://www.famsi.org/mayawriting/codices/marhenke.html.

21 Th. Lee, Los Codices Mayas, Tuxtla Gutierrez 1985, pp. 34-35. 
56 pages painted on both sides, although it was initially divided into two independent parts, known as the Codex Troano (35 sheets) and the Codex Cortesianus ( 21 sheets). In 1880, French researcher Leon de Rosny noticed that both manuscripts are fragments of the same document. The Codex Troano, owned by Juan de Tro y Ortolano, was finally acquired in 1888 by the then Archaeological Museum in Madrid, which from 1875 had already had the Codex Cortesianus in its collection, bought from Jose Ignacio Miró ${ }^{22}$.

The Paris Codex, which has been part of the collection of the National Library of France (Bibliothèque Nationale de France) in Paris since 1832, has 11 pages, written on both sides, measuring $24.8 \times 13 \mathrm{~cm}$ and $1.45 \mathrm{~m}$ in length ${ }^{23}$.

The Maya Codex of Mexico, kept at the National Library of Anthropology and History (Biblioteca Nacional de Antropología e Historia) in Mexico City, was found by looters in a cave in Chiapas in 1965 and bought by a private Mexican collector, Josue Saenz. For many years, it caused controversy among scholars who were not convinced of its authenticity. However, after a thorough epigraphic and iconographic analysis carried out by M. Coe, S. Houston, M. Miller and K. Taube ${ }^{24}$ and thanks to the use of the latest technology by Mexican researchers, which allowed, among others, to determine the chemical composition of the paper and pigments ${ }^{25}$, finally the codex was recognized as one originating in pre-Columbian times. The manuscript has 11 pages painted on one side, the original dimensions being $23 \times 12.5 \mathrm{~cm}$.

Although at the time when the first researchers got interested in the old pre-Columbian books, no one was able to read the glyphs, yet codices played a huge role in the studies into the Ancient Maya civilization. German scholar Ernst Förstmann from the above-mentioned library in Dresden, where one of the manuscripts was stored, having studied glyphs for the days and months of the Maya calendar in the work of D. de Landa, managed to understand the so-called Long Count developed by the Maya, which consists of multiples of five basic time units: $k^{\prime}$ in (day), winal (20 days), tun (360 days), k'atun (7200 days) and bak'tun (144,000 days) and refers to the number of days that have passed since the base date 13.0.0.0.0 4 Ajaw 8 Kumk'u. He also understood that the Maya used the positional vigesimal (base-20) numeral system and explained the calculations of phases of the planet Venus, as well as solar and moon eclipses in the Dresden Codex.

Another German researcher, Paul Schellhas focused on the images of deities presented on pages of the surviving codices, designating a letter of the alphabet

\footnotetext{
22 Ibidem, p. 81-83.

23 Ibidem, p. 143-144.

24 M. Coe, S. Houston, M. Miller, K. Taube, op. cit., pp. 116-183.

25 The results of the analysis were presented at the symposium at the National Museum of Anthropology in Mexico City, on August 30-31, 2018.
} 
to each of them. He identified the physical characteristics and attributes of each individual deity and listed their functions. And it was the extant manuscripts that played a significant role in deciphering the Maya script. Russian scientist Yuri Knorozov, convinced that the Maya writing system was logo-syllabic, not alphabetical as D. de Landa mistakenly had thought, focused on the pages of the Dresden Codex. Taking into account the fact that the textual passages are accompanied by scenes directly related to the text and thus constituting a kind of hint, he managed, among others, to read some of the glyph blocks. Those first works laid the foundations for further epigraphic and iconographic research and for more exact understanding of calendrical and astronomical calculations.

The four manuscripts mentioned above are from the $12^{\text {th }}-15^{\text {th }}$ centuries, the oldest of them being the Maya Codex of Mexico, although as iconographic research has shown ${ }^{26}$, in addition to elements typical of the Maya, it also shows influences from the Toltec, Mixtec and Central-Mexican cultures. Codices: Dresden, Madrid and Paris originate from the northern and eastern parts of the Yucatan Peninsula, today encompassing the Mexican states of Yucatan and Quintana Roo. Although written in the Late Post-Classic Period, they also contain information dating back to the Classic Period. What is more, the fact that the tradition of codex-making was much older is also evidenced by images of scribes preserved on ceramic vessels (Photo 6). The chances of survival of manuscripts from the Classic Period were basically close to none already when Spaniards arrived in the Maya area, because in the humid tropical climate they would not have survived in good condition for hundreds of years. Nevertheless, in several tombs dated to the Classic Period, archaeologists discovered fragments of codices, which, unfortunately, were almost completely destroyed.

Pieces of the amate paper coated with a layer of calcium carbonate were found in Tomb A6 in Group A in Uaxactun (Guatemala). Thanks to the latest technology, Nicholas P. Carter and Jeffrey Dobereiner were able to see the outlines of glyphs and illustrations, and which is particularly interesting, they identified two layers of stucco with different motifs on the pieces of paper. This may indicate that the codex might have been a palimpsest, which would make it the only such a case among Maya manuscripts. The grave and manuscript are from the $5^{\text {th }}$ century, so from the Early Classic Period, which makes it the oldest codex found to date, though some remains of codices were also found at the sites of Nebaj and San Agustín Acasaguastlán (Guatemala) and Altun Ha (Belize) $)^{27}$.

26 M. Coe, S. Houston, M. Miller, K. Taube, op. cit., p. 157.

27 N.P. Carter, J. Dobereiner, Multispectral imaging of an Early Classic Maya Codex fragment from Uaxactun, Guatemala, "Antiquity” 2016, vol. 90, no. 351, pp. 711-725. 
Remains of manuscripts from the Classic Period, although impossible to read, were also found in the Maya city of Copan (Honduras) in Tomb VIII-36 in Group $9 \mathrm{~N}-8$, probably belonging to a priest living in the $5^{\text {th }}$ century, and in Tomb XXXVII-4 in the structure Chorcha, where the king K'ahk' Uti' Witz' $K^{\prime}$ 'awiil, who ruled for 67 years starting in 628 , was buried ${ }^{28}$.

\section{Topics raised in manuscripts}

The content of the surviving codices is rather uniform, because they all mainly contain almanacs with auguries for particular days, referring to the sacred Tzolk'in calendar of 260 days and the Haab calendar based on the solar year of 365 days. Individual almanacs, organized in horizontal sections, could extend over several subsequent pages. Thanks to them, priests knew when and what offerings should be prepared for specific Maya gods to win their favour, what misfortunes could be expected, or what rituals need to be performed. The almanacs allowed to identify days appropriate for undertaking various activities related, for example, to agriculture, hunting, weaving, beekeeping (Photo 7) or carving figurines of deities. The Maya believed in the cyclical nature of events and they wanted to be properly prepared for their repetition. The same was true for periods called k'atuns, covering about 20 years (7200 days), which were extremely important for the Maya. Because each of $k$ 'atuns ended on an Ajaw day with an associated numerical coefficient of 1 to 13, it was believed that another day with the same name may bring a similar event.

Some pages of the Dresden Codex also show New Year ceremonies, mentioned by bishop D. de Landa and similar to those described in the Classic Period inscription painted on the wall of one of the palace chambers in the Maya city of Ek' Balam (Mexico) ${ }^{29}$.

In addition, the existing Maya codices contain tables of phases of Venus and eclipses of the Sun and Moon - the result of observations carried out with the naked eye for hundreds of years. Basically, we should speak of astrology here, because for the Maya both the Sun and the Moon and Venus, whose two aspects were the Morning Star and the Evening Star, were deities and therefore had a direct impact on the fate of people and the world. It was believed that the Sun after sunset or Venus temporarily invisible in the sky embark on a journey through the Underworld and only overcoming the forces of darkness will allow them to reappear in the firmament. The Maya sought harmony in the Universe and, through appropriate multiples, sought to combine their ritual and solar calendars with the cycle of Venus and even of Mars. For many years, the

\footnotetext{
28 W. Fash, op. cit., pp. 91, 122.

29 A. Lacadena, Los jeroglificos de..., p. 66.
} 
surviving codices were the only example of astronomical calculations of the Maya. It was only in 2011 that tables dating to the beginning of the $9^{\text {th }}$ century and containing calculations referring to the Moon and probably to Venus and Mars were discovered in the Classic Maya city of Xultun (Guatemala). They survived on a wall of a building and resemble entries in the Dresden Codex. As emphasized by W.A. Saturno, David Stuart, Anthony F. Aveni and F. Rossi, this finding confirms that the Post-Classic manuscripts were based on much earlier calculations ${ }^{30}$.

Most of the painted glyphic books were probably almanacs containing ritual and astronomical information, and since those were used by priests in many centres, there was a need to rewrite them in numerous copies. D. de Landa, describing celebrations of rituals associated with individual months of the calendar, mentions even that in the month Wo priests met in the ruler's house and after ritual censing and cleansing books with spring water, they checked auguries for the year and gave appropriate recommendations to the people present at the ceremony ${ }^{31}$. Such manuscripts could be kept in archives or in temples and houses of priests. Regardless, it is more than likely that they were transported in boxes, especially when priests travelled to other centres. A very interesting finding is a basalt box (Photo 8) discovered by Arthur Demarest in the Alta Verapaz region (Guatemala), in the Hun Nal Ye cave, which has been a pilgrimage destination for the Maya since at least Early Classic Period ${ }^{32}$. According to scholars, the box placed in the cave around 200-500 AD, must have contained a codex, which is indicated not only by its size, but also by scenes decorating its sides, depicting characters with manuscripts in their hands.

However, could the codices destroyed by Spanish missionaries or written in the Classic Period be devoted to other topics? To some extent, the Colonial chroniclers offer an answer to this question. A. de Ciudad Real points out that the Maya also recorded their histories ${ }^{33}$, and J. de Acosta adds that the books contained knowledge about plants and animals ${ }^{34}$. Then, D. López de Cogolludo also mentions references to wars and natural disasters, as well as stories of the creation of the world and people ${ }^{35}$.

30 W.A. Saturno, D. Stuart, A.F. Aveni, F. Rossi, Ancient Maya Astronomical Tables from Xultun, Guatemala, "Science” 2012, vol. 336, pp. 714-717.

31 D. de Landa, op. cit., p. 103.

32 A. Demarest, The Cave of Hun Nal Ye and its treasures and sacred coffer, [in:] Maya III. Life-Death-Time, ed. M. Didrichsen and H. Kettunen, Helsinki 2012, pp. 53-57.

33 J.E. Thompson, op. cit., p. 16.

34 J. de Acosta, op. cit., p. 160.

35 D. López de Cogolludo, op. cit., pp. 273-274. 
Furthermore, D. de Landa emphasizes that the Maya were proud of their ancestors and they would visit priests to learn about their own family histories $^{36}$. This indicates that genealogical manuscripts must also have existed, and it certainly wasn't true only for the Post-Classic Period. Given the fact that fragments of codices were found in royal tombs in Altun Ha (Belize) and Copan (Honduras), one may wonder about the possible content of those books. It seems unlikely that they contained typical almanacs, because their interpretation was the responsibility of priests; it is more probable that they were of historical nature, and contained for example the history of the dynasties of those cities. Moreover, in the most powerful Maya kingdoms, for example Tikal (Guatemala) or Calakmul (Mexico), whose rulers conquered other cities and collected tributes from their vassals, the courts probably also kept records of such tributes. However, these types of manuscripts were of local nature and thus limited only to specific cities. Some of them may have been destroyed in pre-Columbian times, for example during times of war, when chances of making new copies and keeping them safe were limited.

Despite the destruction of pre-Columbian documents, some of the information contained therein has survived, because when the Maya started learning the Latin alphabet, they decided to use it to rewrite the old glyphic books and thus to preserve their historical and religious content for posterity. Particularly noteworthy are several Books of Chilam Balam, originating in different cities on the Yucatan Peninsula, among others Chumayel, Tizimín, Maní, Kaua and Ixil (Photo 9), written in the Yukatekan language at different periods of time, sometimes with visible colonial influences. Alfredo Barrera Vásquez and Silvia Rendón ${ }^{37}$ believe that in each of the towns, the original text was regularly completed with new material, and the extant copies are not originals from the $16^{\text {th }}$ century, but copies of copies made in later times. Their content is diverse and, apart from almanacs similar to those of the Dresden and Madrid Codices, includes historical chronicles, prophecies, religious hymns, descriptions of rituals, creation stories, and healer recommendations, which may be indicative of the topics covered in glyphic manuscripts that have not survived to our time.

Another significant document, written in the Latin alphabet and in the K'iche'an language, which was used by the Maya in Guatemalan Highlands, is the book entitled Popol Vuh, dating from the $16^{\text {th }}$ century, but kept hidden from Spaniards until the early $18^{\text {th }}$ century, when friar Francisco Ximénez, serving as a priest in Chichicastenango (Guatemala), had the opportunity to see the work and translated it into Spanish. It is not known who wrote or compiled individual

36 D. de Landa, op. cit., p. 48.

37 A. Barrera Vásquez, S. Rendón, El Libro de los Libros de Chilam Balam, México 1992, pp. 10-11. 
fragments of the book, but it is worth noting that the parts about mythical events clearly refer to scenes depicted on Maya ceramics from the Classic Period, which suggests that the subject matter goes back to much earlier times and manuscripts dealing with mythology might also have existed back then. Especially vessels made in the so-called Codex style (Photos 10a-c) deserve special attention: their composition, colour palette and character presentation resemble pages of manuscripts, especially the Dresden Codex.

Additionally, examples of old Maya lyrical poetry have survived in songs that Mexican researcher A. Barrera Vásquez called Cantares de Dzitbalché. Although the extant lyrics of the songs, which were once accompanied by music and dance, come from the $18^{\text {th }}$ century, but they are probably copies of much earlier, $15^{\text {th }}$-century texts and, according to John Curl, they could have been written on the basis of a pre-Columbian manuscript ${ }^{38}$.

The K'iche' Maya from Gumarcaaj and Rabinal (Guatemala) have also preserved a dance-drama entitled Rabinal Achi, known to them since the $12^{\text {th }}$ century, although in this case we cannot be sure if the drama was ever recorded in writing, since a lot of knowledge was passed down orally from generation to generation, and oral tradition was deeply rooted in Maya culture. On the other hand, according to Ralph Roys, it is very likely that the so-called Ritual de los Bacabes, written in the $18^{\text {th }}$ century and containing shamanic incantations, was copied from much older manuscripts dating back to the period before the arrival of Spaniards ${ }^{39}$.

\section{Language used in manuscripts}

In order to decipher Maya glyphic inscriptions, it was first necessary to determine in what language they were written, because today the Mayan linguistic family counts about 30 languages, originating from Proto-Mayan. S. Houston, D. Stuart and John Robertson ${ }^{40}$ introduced the concept of the Classic Mayan language, which exhibits closest similarities to colonial Ch'olti' and contemporary Ch'orti'. It was a prestige language used in writing, regardless of the vernacular spoken by inhabitants of a given region. In the case of manuscripts from the Post-Classic, the glyphic texts contained therein were written in both Yukatekan and Classic Mayan, as demonstrated by

38 J. Curl, Ancient American Poets, Tempe 2005, pp. 57-58.

39 R.L. Roys, Ritual of the Bacabs, Norman 1965, p. VII.

40 S. Houston, J. Robertson, D. Stuart, The Language of Classic Maya Inscriptions, "Current Anthropology" 2000, vol. 41, no. 3, pp. 321-356. 
A. Lacadena ${ }^{41}$ and Robert Wald ${ }^{42}$ with reference to the Madrid and Dresden Codices, respectively.

While most of the inscriptions carved on stone monuments are much more accessible and easier to read, understanding the content of surviving codices is much more complicated not only because of the esoteric character of their subject matter, but also because of the language used. Although some of the texts preserved on stelae and panels have a literary flavour and stylistic finesse, which scribes utilized to turn them into masterpieces, the almanacs in the Dresden, Madrid and Paris Codices seem to be brimming with rhetorical figures. A. Lacadena enumerates, among others, allegories, alliterations, anaphors, hyperboles, homophones, metaphors, metonymies, parallelisms, personifications and synonyms, all of which affect phonology, morphology, syntax, semantics and the expressiveness of texts. The same stylistic ornamentation also appears in the above-mentioned texts rewritten in the Latin alphabet after the Spanish conquest. Kerry Hull, referring to earlier works by Clemency Coggins, reports that in colonial sources we find information about the existence of the sacred language zuyua, mentioned in the $16^{\text {th }}$ century in Yucatan, full of wordplay, metaphors, homophones, synonyms and polysemy, and understood only by priests and rulers ${ }^{43}$. Dennis Tedlock also points out that in the Books of Chilam Balam, the term suyua t'an refers to "deceptive speech with twisted words" 4 . All this makes the translation of those texts into Indo-European languages extremely difficult and reflecting their original message may be a real challenge ${ }^{45}$.

Visual imagination played a significant role in the creation and reception of painted books of the Maya. The narrative was developed by both the glyphic text and iconography. The almanacs usually contained short textual passages accompanied by illustrations, but this explicit information was only a clue to the priest, because it was important not only to read the text but, above all, to interpret it properly. D. de Landa mentions that priests specializing in this art were called Chilan $^{46}$ and they were the ones who were able to communicate the will of gods.

41 A. Lacadena, Bilingüismo en el Códice de Madrid, "Los Investigadores de la Cultura Maya" 1997, vol. 5, pp. 184-204.

42 R. Wald, The Languages of the Dresden Codex, [in:] The Linguistics of Maya Writing, ed. S. Wichmann, Salt Lake City 2004, pp. 27-58.

43 K. Hull, Verbal Art and Performance in Ch'orti 'and Maya Hieroglyphic Writing, unpublished Ph.D. dissertation, 2003, pp. 322-323.

44 D. Tedlock, Popol Vuh. The Mayan Book of the Dawn of Life, New York 1996, p. 295.

45 A. Lacadena, Apuntes para un estudio de literature maya antigua, [in:] Text and Context: Yucatec Maya Literature in a Diachronic Perspective, ed. A. Gundenheimer, T. Okoshi Harada and J.F. Chuchiak, Akwizgran 2009, p. 33.

46 D. de Landa, op. cit., p. 55. 


\section{Summary}

While only four Maya painted books have survived to this day, and they contain mainly ritual and astronomical information, nevertheless, the records of chroniclers and documents rewritten in the Latin alphabet in Colonial times testify to the great variety of topics that could have been raised in the lost codices. On the other hand, although research on the pre-Columbian manuscripts has been going on for many years and will certainly be continued, we will probably never be able to interpret their content the way the Maya did and explore all the information encoded in them.

\section{Acknowledgements}

I would like to thank Agnieszka Hamann for translating my article into English.

\section{References}

Acosta, J. de, Historia natural y moral de las Indias, Madrid 1894.

Barrera Vásquez A., Rendón S., El Libro de los Libros de Chilam Balam, México 1992.

Carter N.P., Dobereiner J., Multispectral imaging of an Early Classic Maya Codex fragment from Uaxactun, Guatemala, “Antiquity” 2016, vol. 90, no. 351, pp. 711-725.

Coe M.D., Kerr J., The Art of the Maya Scribe, 1998.

Coe M., Houston S., Miller M., Taube K., The Fourth Maya Codex, [in:] Maya Archaeology 3, ed. Ch. Golden, S. Houston, J. Skidmore, San Francisco 2015, pp. 116-167.

Chuchiak J.F., The Images Speak: The Survival and Production of Hieroglyphic Codices and Their Use in Post Conquest Maya Religion (1580-1720), "Acta Mesoamericana" 2004, vol. 14, pp. 165-183.

Curl J., Ancient American Poets, Tempe 2005.

Demarest A., The Cave of Hun Nal Ye and its treasures and sacred coffer, [in:] Maya III. Life-Death-Time, ed. M. Didrichsen and H. Kettunen, Helsinki 2012, pp. 46-59.

Fash W.L., Scribes, warriors and kings. The City of Copán and the Ancient Maya, London 2001.

Houston S., Robertson, J., Stuart D., The Language of Classic Maya Inscriptions, "Current Anthropology" 2000, vol. 41, no. 3, pp. 321-356.

Hull K., Verbal Art and Performance in Ch'orti' and Maya Hieroglyphic Writing, unpublished Ph.D. dissertation, Austin 2003.

Inomata T., The Power and Ideology of Artistic Creation: Elite Craft Specialists in Classic Maya Society, „Current Anthropology” 2001, vol. 42, no. 3, pp. 321-349.

Lacadena A., Bilingüismo en el Códice de Madrid, "Los Investigadores de la Cultura Maya" 1997, vol. 5, pp. 184-204. 
Lacadena A., Los jeroglificos de Ek’ Balam, „Arqueología Mexicana” 2005, vol. 13, no. 76, pp. 64-69.

Lacadena A., Apuntes para un estudio de literatura maya antigua, [in:] Text and Context: Yucatec Maya Literature in a Diachronic Perspective, ed. A. Gunsenheimer, T. Okoshi Harada and J.F. Chuchiak, Aachen 2009, pp. 31-52.

Landa D. de, Relación de las cosas de Yucatán, Merida 1986.

Lee Th.A., Los Códices Mayas, Tuxtla Gutierrez 1985.

López de Cogolludo D., Historia de Yucatán, Barcelona 2008.

Restall M., Chuchiak J., A Reevaluation on the Authencity of Fray Diego de Landa' a Relación de las cosas de Yucatán, „Ethohistory” 2002, vol. 49, no. 3, pp. 651-669.

Rossi F.D., Saturno W.A., Hurst H., Maya Codex Book Production and the Politics of Expertise: Archaeology of a Classic Period Household at Xultun, Guatemala, „American Anthropologist" 2015, vol. 117, pp. 116-132.

Roys R.L, The Book of Chilam Balam of Chumayel, Washington 1933.

Roys R.L., Ritual of the Bacabs, Norman 1965.

Saturno W.A., Stuart, D., Beltrán, B., Early Maya Writing at San Bartolo, Guatemala, „Science” 2006, vol. 311, pp. 1281-1283.

Saturno W.A., Stuart D., Aveni A.F., Rossi F., Ancient Maya Astronomical Tables from Xultun, Guatemala, "Science" 2012, vol. 336, pp. 714-717.

Tedlock D., Popol Vuh. The Mayan Book of the Dawn of Life, New York 1996.

Thompson J.E., Un Comentario al Códice de Dresde, México 1988.

Wald R., The Languages of the Dresden Codex, [in:] The Linguistics of Maya Writing, ed. S. Wichmann, Salt Lake City 2004, pp. 27-58.

Photo 1. Maya bark beater with grooves used in paper production. Museo Nacional de Arqueología y Etnología, Guatemala City.

Photo by B. Tuszyńska, 2011

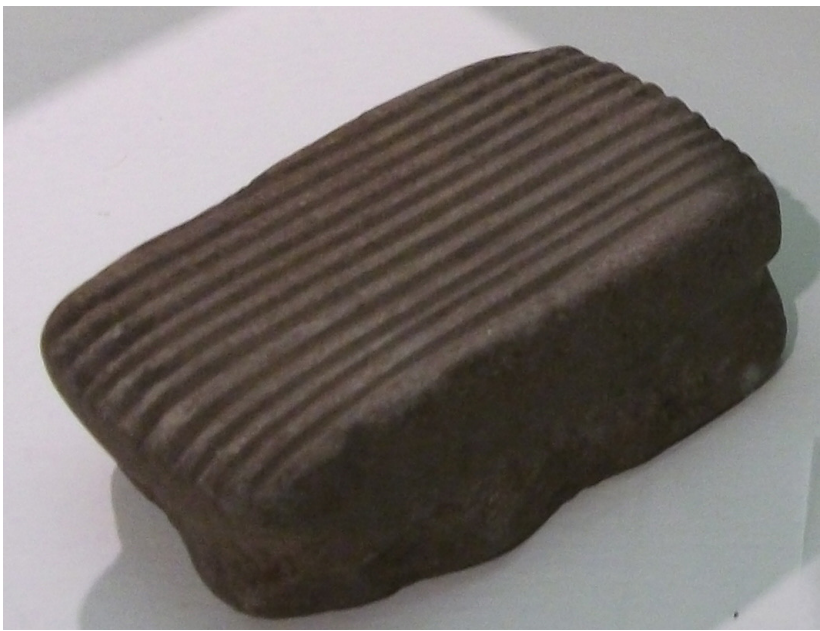


Photo 2. A glyph block with the word hu'un written as a logogram with a phonetic complement /HUN-na/. Detail from Stela 8 at Dos Pilas (Guatemala). Photo by B. Tuszyńska, 2005

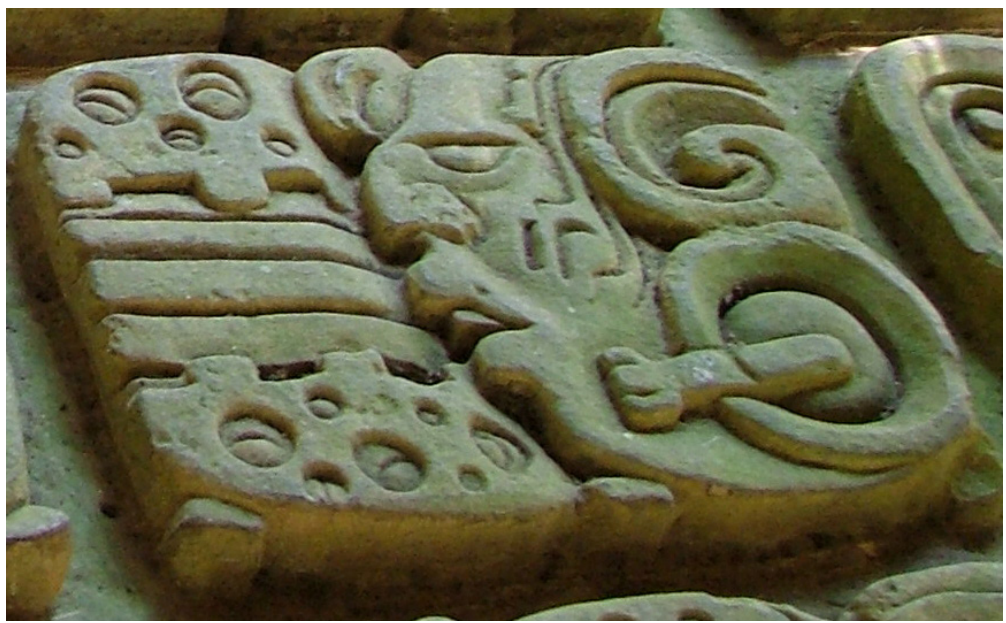

Photo 3. Shell used as a container for paint. Zaculeu archaeological site (Guatemala). Photo by B. Tuszyńska, 2011

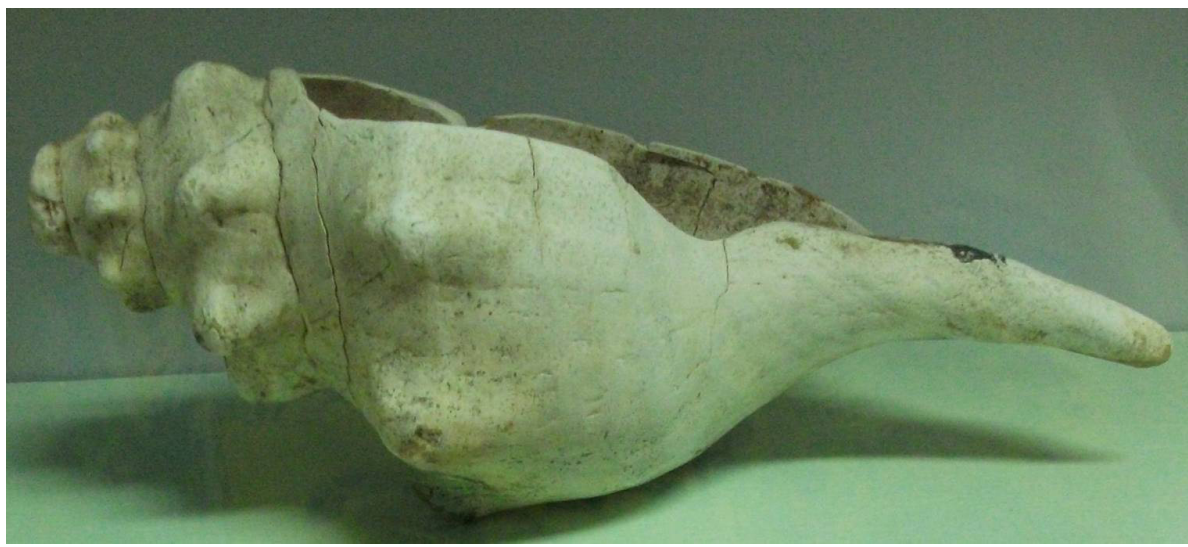


Photo 4. Structure 9N-82 in Copan (Honduras), a residence of scribes.

Photo by B. Tuszyńska, 2009

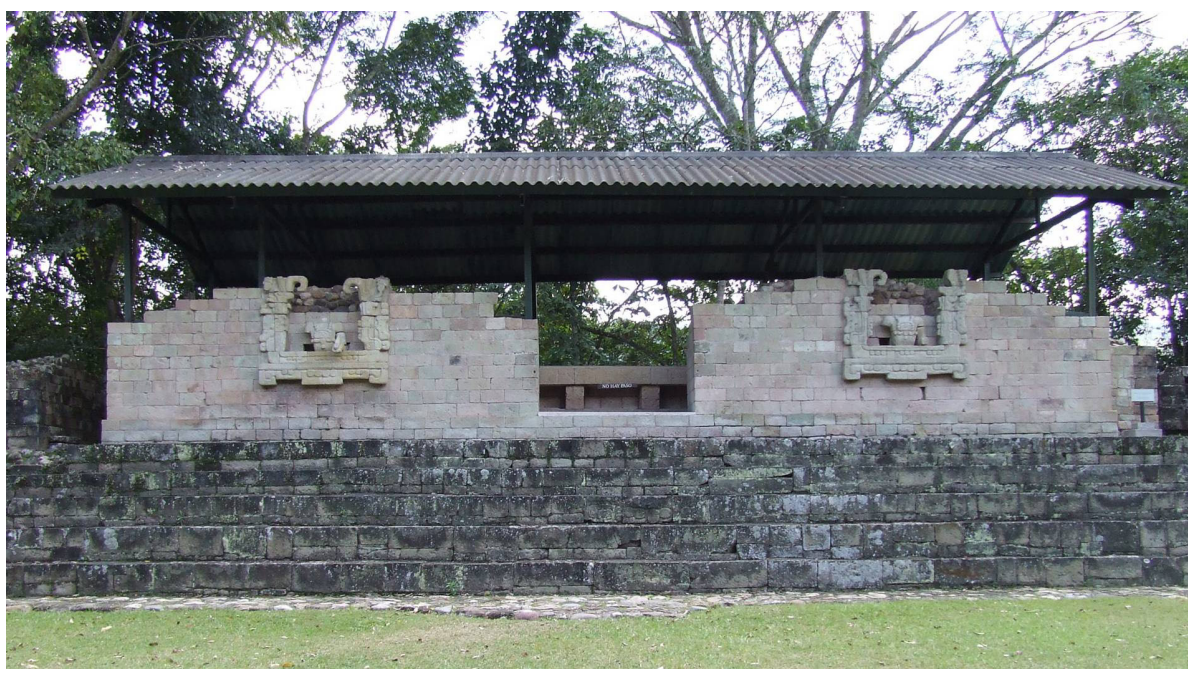

Photo 5. Pages 80-83 of the Madrid Codex. Copy in Gran Museo del Mundo Maya, Merida (Mexico). Photo by B. Tuszyńska, 2019

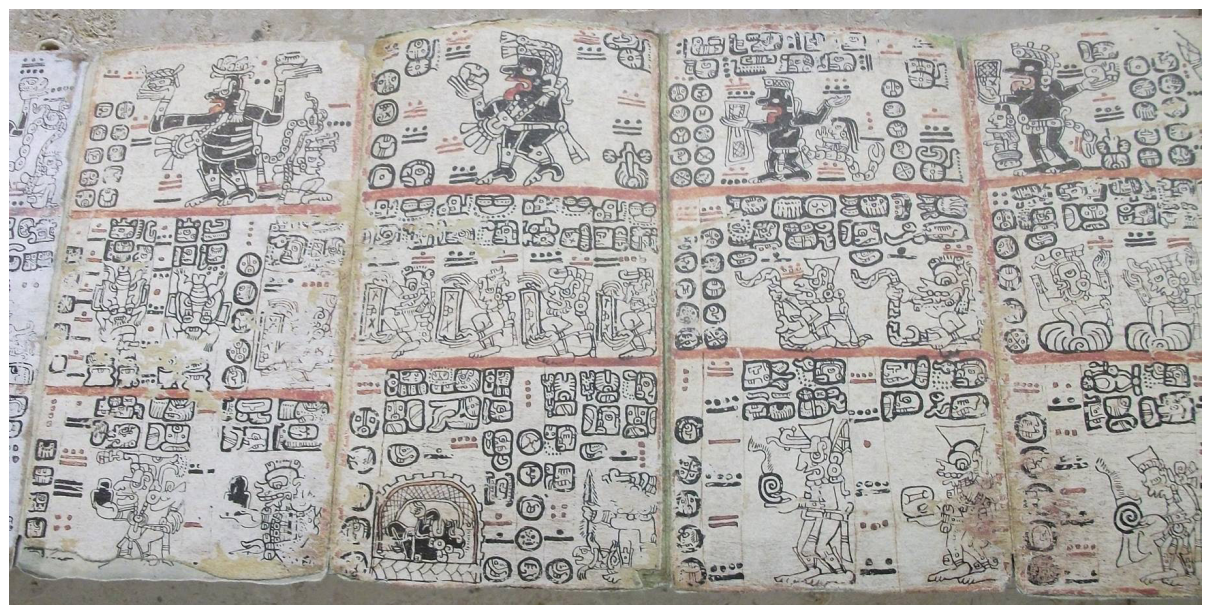


Photo 6. A ceramic pot from the Classic Period, depicting a scribe-painter writing a codex. Museo Nacional de Antropología, Mexico City.

Photo by B. Tuszyńska, 2015

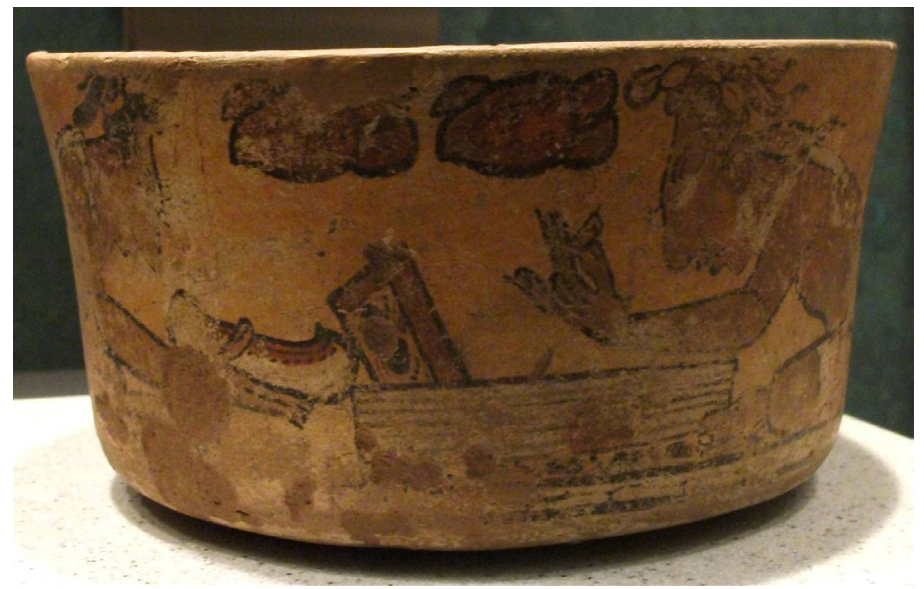

Photo 7. Fragments of almanacs on pages 105-106 of the Madrid Codex referring to beekeeping. Copy in Gran Museo del Mundo Maya, Merida (Mexico).

Photo by B. Tuszyńska, 2019

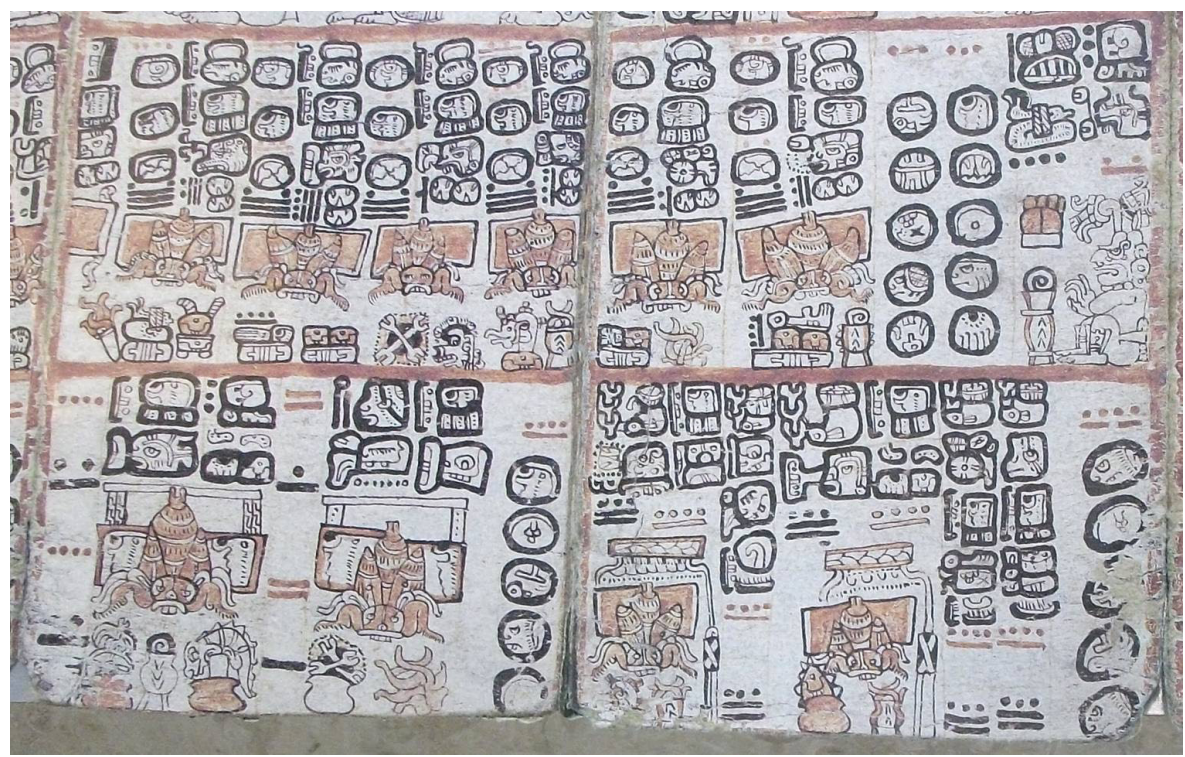


Photo 8. A stone box found in the cave of Hun Nal Ye, Museo Nacional de Arqueología y Etnología, Guatemala City. Photo by B. Tuszyńska, 2011

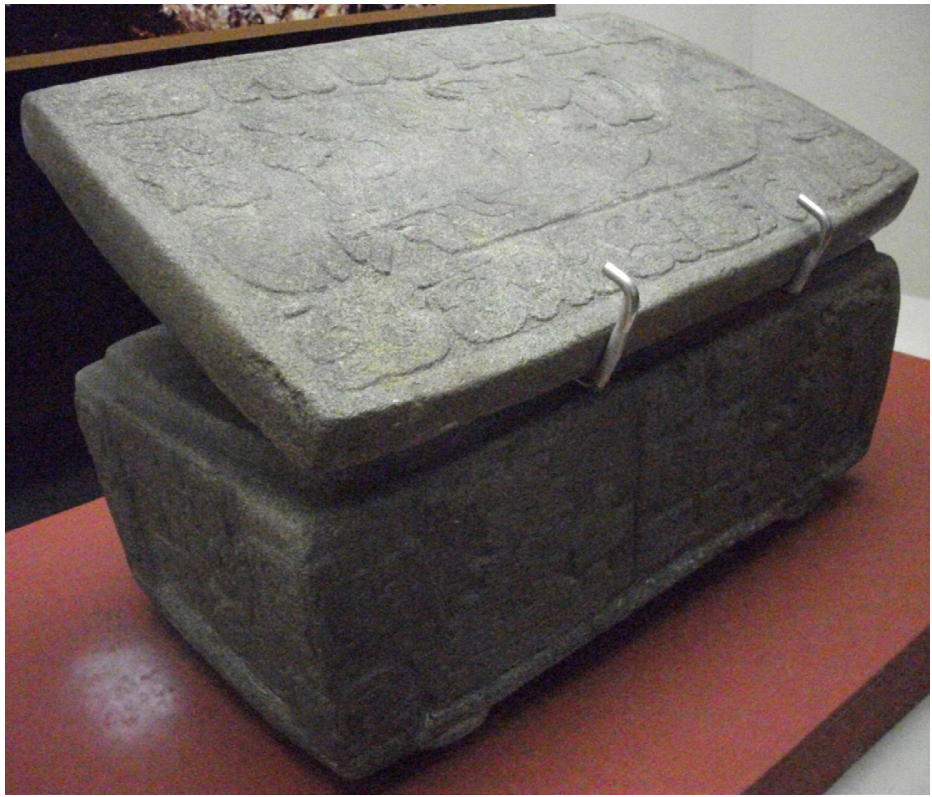

Photo 9. The Book of Chilam Balam from Ixil. Copy in Museo Nacional de Antropología, Mexico City. Photo by B. Tuszyńska, 2019

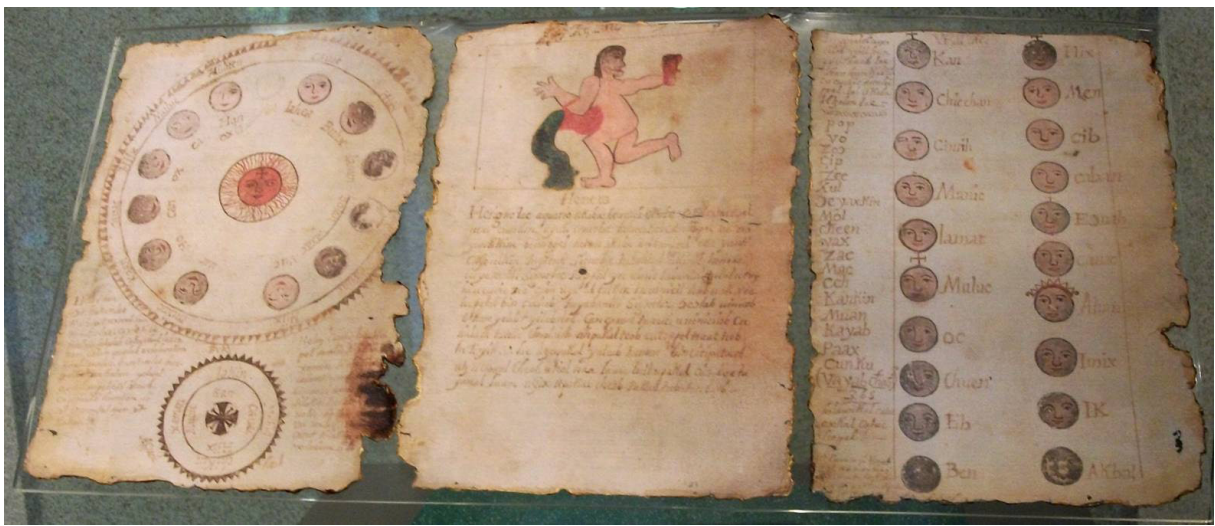


Photo 10. Maya vases made in the so-called Codex style. Museo Nacional de Antropología, Mexico City (a), Museo Nacional de Arqueología y Etnología, Guatemala City (b), Museo Maya de Cancun (c).

Photos by B. Tuszyńska, 2019, 2012, 2013

(a)

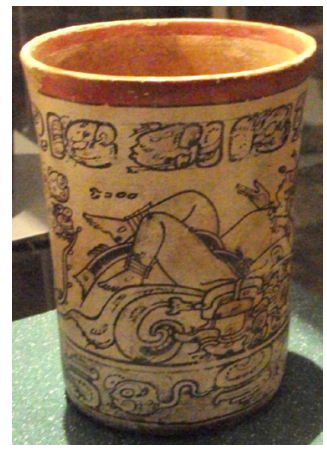

(b)

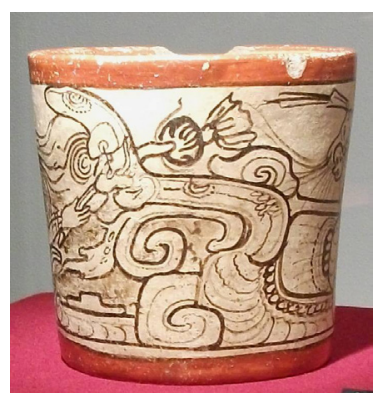

(c)

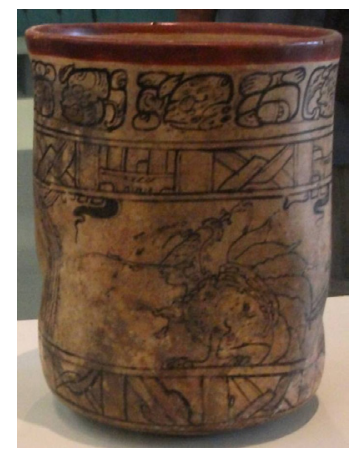

